\title{
CAPITAL STRUCTURE AND PERFORMANCE: EVIDENCE FROM EUROPEAN LISTED COMPANIES
}

\author{
DOI: 10.17261/Pressacademia.2019.1171 \\ JBEF- V.8-ISS.4-2019(8)-p.259-267 \\ Carmelo Intrisano ${ }^{1}$, Anna Paola Micheli ${ }^{2}$, Anna Maria Calce ${ }^{3}$ \\ ${ }^{1}$ University of Cassino and Southern Lazio, Italy \\ c.intrisano@unicas.it, ORCID: 0000-0002-8990-3366 \\ ${ }^{2}$ University of Cassino and Southern Lazio, Italy \\ annapaola.micheli@unicas.it, ORCID: 0000-0003-1150-1874 \\ ${ }^{3}$ University of Cassino and Southern Lazio, Italy \\ annamariacalce@unicas.it,ORCID: 0000-0003-1877-9932
}

Date Received: November 19, 2019

Date Accepted: December 24, 2019

To cite this document

Intrisano, C., Micheli, A. P., Calce, A. M., (2019). Capital structure and performance: evidence from European listed companies. Journal of Business, Economics and Finance (JBEF), V.8(4), p.259-267.

Permemant link to this document: $\underline{\text { http://doi.org/10.17261/Pressacademia.2019.1171 }}$

Copyright: Published by PressAcademia and limited licenced re-use rights only.

\begin{abstract}
Purpose - The paper aims to investigate the existence of a relationship between financial structure and performance for European listed companies.

Methodology - The reference period of the study is three years (2015-2017). In line with Modigliani and Miller' Theory we assume that independent variable (debt/equity ratio) does not influence performance (measured by ROE and ROA). We use correlation and linear regression analysis.

Findings - Results show the existence of a weak relationship between capital structure expressed as debt/equity ratio and performance measures. However, the $\mathrm{R}^{2}$ of the model has a limited explanatory capacity, so only an insignificant part of the variability of performance measures can be explained by changes in capital structure. The remaining part depends on factors not included in the linear models formulated.

Conclusion- The study shows that the financial structure does not condition the economic and financial performance of European listed companies.
\end{abstract}

Keywords: Capital structure, performance, value, corporate finance

JEL Codes: G00, G32, G39

\section{INTRODUCTION}

Financial structure refers to the mix of financing sources available to companies. The most common sources are represented by debt and equity. The way companies choose to finance their activities can reflect on their performance and value creation. This concept is explained in the leverage mechanism that links the return on equity (ROE) to the return on investment (ROI), the return on debt (ROD) and the financial structure.

Several theories have been developed over time with a focus on the capital structure: the reference is to the Classical Theory of Modigliani and Miller (according to which the choice of the financial structure does not affect the creation of value by the companies), to the Trade Off Theory (according to which a company chooses the debt and equity by balancing the related costs and benefits) and to the Pecking Order Theory. The latter states that companies follow an order of preference in the choice of financial resources, preferring firstly internal resources and, only where these resources are insufficient, companies would resort to the banking channel or to the issue of shares. Companies can affect their choices of financial structure using different tools. Among these are the shareholders' agreements, the pyramidal groups and the dual class models that allow the separation between ownership and control. 
Since 1958 the search for the relationship between capital structure and performance has always been discussed in the literature. Many Authors treated this theme investigating how the choice of financing methods by companies can affect their economic and financial performance and the value creation process. The studies developed on this field came to the identification of controversial results: some of them highlighted the existence of a positive relationship, others determine a negative relationship. In other cases, Authors found a relationship not statistically significant. This work intends to contribute to the literature trying to estimate the impact that financial structure has on profitability of the European listed companies.

\section{LITERATURE REVIEW}

Miller (1977) concluded on the existence of a positive correlation between the financial leverage and the value of the company.

Some authors have not found a connection between debt and company profitability. Long and Maliz (1986), as well as Fama and French (1998) concluded that there is no link between the financial structure and profitability of the companies.

Other Authors identified the existence of a negative relationship between financial structure and performance. In particular, a negative effect of the debt on profitability was confirmed by Majumdar and Chhibber (1999), Eriotis and al. (2002), Ngobo and Capiez (2004), Goddard and al. (2005), Rao and al. (2007), Zeitun and Tian (2007).

Majumdar and Chhibber (1999) examine for a sample composed of Indian companies the link between debt levels in the financial structure and their performance: this relationship for Indian companies was found significantly negative.

Eriotis and al. (2002) investigate the relationship between leverage, calculated as the ratio between debt capital and equity, and the profitability of the company. The study was based on panel data for various sectors, referring to the 1995-1996 period. Authors showed that companies which finance their investment activities through self-financing are more profitable than companies that adopt a more debt-oriented financial structure.

Sarkar and Zapatero (2003) find a positive relationship between financial leverage and profitability.

Ngobo and Capiez (2004) based their analysis on listed companies of different countries. Data collected concerned the period from 1992 to 2002. They analyzed 166,320 data. Three performance measures were taken into consideration: company performance, financial performance and market value. The commercial performance was measured by the sales growth rate. The financial performance was measured by the Return on Assets (ROA) while the value of the company was measured by the ratio between market value and value accounting (market to book value). The analysis showed that global debt was negatively correlated with performance.

Goddard and al. (2005) wanted to identify the determinants of profitability for the manufacturing and services sectors in Belgium, France, Italy and the United Kingdom. The analysis was developed for the period 1993-2001 finding a negative relationship between the debt ratio of a company and its profitability.

Joshua Abor (2005) identified in his study the presence of a significantly positive relationship between leverage and ROE. Leverage was calculated as short-term debt to total assets ratio. At the same time a negative relationship was found between another configuration of leverage, calculated in this case by relating long-term financing to total assets, and ROE. Analysis showed a significantly positive association between the "total debt / total assets" ratio and the return on equity.

Mollik (2005) discovered the existence of a positive association between financial leverage and performance.

Baum and al. (2006) using the Compustat and Bundesbank databases analyzed the impact of financial structure on performance for companies located in Germany and in the United States. The US sample consists of a panel of about 15,000 manufacturing companies for the period 1984-2004. The Bundesbank database takes on average 125,000 annual company data in the period from 1988 to 2000 . Authors used in their analysis variables as net profit, total assets, cash flows, ROA and the turnover to total assets ratio. The independent variable was the short-term debt (calculated as current liabilities to total liabilities ratio). Authors hypothesized that the profitability of the companies varies according to the expiry of the funding sources. Sensitivity to the duration of funding was statistically significant in Germany, but not in the United States.

Pornsit and Yixin (2007) analyzed the relationship between capital structure and business value. The results did not demonstrate any significant negative impact on the value of the company due to excess financial leverage. 
Walaa (2007) investigated the impact of the financial structure on business value. The empirical results show that the debt/equity ratio had no impact on the value of the company.

Zeitun (2007) analyzed the Jordanian companies in the period 1989-2003 showing that the capital structure of a company had a statistically significant negative impact on the performance measures of the company. Furthermore, the level of short-term debt relative to total assets has a positive effect on the measurement of market performance (Tobin's Q). The panel consists of 167 companies of 16 economic sectors. Financial companies, such as banks, insurance companies, were excluded from the analysis. Which company performance measures were used asset return (ROA), return on equity (ROE), earnings before interest and taxes plus amortization on total assets (variable named PROF), market value of equity plus book value of the debt in relation to the book value of the assets (Tobin's Q), market value of the equity in relation to the related book value (MBVR), price to earnings $(P / E)$ and market value of the equity and book value of the liabilities in relation to the book value of the own capital (MBVE). Capital structure of a company had a significant and negative impact on performance measures expressed in both accounting and market terms. The relationship between short-term debt and total assets had a positive and significant effect on Tobin's $Q$.

Arulvel and Ajanthan (2013) in their study investigated the ability of the financial structure to influence business performance. The analysis involved companies listed on the Colombian Stock Exchange and was based on the period 2007-2011. The financial structure was expressed by the debt/equity ratio and the debt ratio. Performance variables were instead represented by ROE, EPS (Earning per share), pre-tax result and net result. The study revealed a negative relationship between financial structure and performance.

Mujahid and Akhtar (2014) evaluated the impact of capital structure on financial performance of companies in the textile sector in Pakistan. 155 textile companies were analyzed for the period 2006-2011. ROA, ROE and the EPS ratio (Earning per share) were used as measurement of profitability. The results showed that capital structure had positive impact on the financial performance of companies.

Mashavave and Tsaurai (2015) analyzed the impact of financial structure on performance measures. The sample was composed of companies listed on the Johannesburg Stock Exchange in South Africa. Authors used the debt/equity ratio as independent variable; the profit margin was used as a dependent variable. The analysis showed the absence of relationship between the two variables.

Rahimian (2016) investigated the existence of a relationship between financial structure and value (measured through ROE, ROA and Profit on sales variables). Authors based their analysis on $\mathrm{n}$. 157 companies listed on the Tehran Stock Exchange and for the period 2004-2012. Results showed a negative relationship between capital structure and ROA. On the other side, no significant relationship was found between financial structure and ROE. With reference to the variable Profit on sales, the analysis showed a negative relationship with capital structure.

Filipovic and Demirovic in a 2016 paper tested the correlation between financial structure (debt capital) and profitability (measured by ROA and ROE ratios). For the research, Authors used the simple linear regression methodology. The panel consists of listed companies in Montenegro. Authors concluded that a relationship exists between these variable in the case of companies listed on the Montenegro Stock Exchange. Research showed a negative impact of debt (financial leverage) on the profitability measured by ROA and ROE: an increase in debt is reflected in the decrease in return on equity due to the increase in financing costs.

\section{DATA AND METHODOLOGY}

The empirical analysis is based on European listed companies extracted using the Amadeus database of Bureau van Dijk. At the beginning of April 2019, n. 9,625 companies with annual operating revenue exceeding 1 million euros were listed in the States of the Europe 28 area.

For the construction of the sample, we excluded from the reference population n. 1,565 companies listed on the English market because we want to compare companies of homogeneous financial markets and n. 3,527 companies whose activity is identified by the Nace codes Rev. 2 n. 64 and n. 66 relates to the provision of financial services and auxiliary activities of financial and insurance services because of the different legislation concerning the preparation of the financial statements in these sectors.

So, the initial sample consists of n. 4,533 listed companies. 
After we eliminated companies with negative shareholders' equity and that with anomalous values. For their individuation we computed a lower limit (also called lower inner fence) and an upper limit (the so-called upper inner fence) on the basis of the following formulas:

$$
\begin{aligned}
& \text { lower inner fence }=\mathrm{Q} 1-1.5 * \mathrm{IQ} \\
& \text { upper inner fence }=\mathrm{Q} 3+1.5 * \mathrm{IQ}
\end{aligned}
$$

The sample size will not be constant, but will vary due to the different years on which the study is developed.

The correlation and regression analysis was used to identify the relationship between the dependent and independent variable. To interpret the strength of the relationship between the variables, we referred to the guide of Evans which report the value indicated in Table 1:

\section{Table 1: Strength of the Correlation}

\begin{tabular}{ll}
\hline \multicolumn{1}{c}{$\boldsymbol{\rho}$} & Relationship \\
\hline$-1,00<\rho<-0,80$ & very strong \\
$-0,79<\rho<-0,60$ & strong \\
$-0,59<\rho<-0,40$ & moderate \\
$-0,39<\rho<-0,20$ & weak \\
$-0,19<\rho<0,00$ & vey weak \\
$0,00<\rho<0,19$ & very weak \\
$0,20<\rho<0,39$ & weak \\
$0,40<\rho<0,59$ & moderate \\
$0,60<\rho<0,79$ & strong \\
$0,80<\rho<1,00$ & very strong \\
\hline
\end{tabular}

We used as dependent variable ROE and ROA calculated as follow:

$$
\begin{gathered}
R O E=\frac{N E T \text { INCOME }}{\text { SHAREHOLDERS EQUITY }} \\
\text { ROA }=\frac{\text { NET INCOME }}{\text { TOTAL ASSETS }}
\end{gathered}
$$

The independent variable is capital structure expressed through the debt/equity ratio.

Simple linear regression was used to estimate the relationship between financial structure and performance. In particular, the following models have been formulated:

$R O E={ }_{1} \beta_{0}+{ }_{1} \beta_{1} \times \frac{D}{E}+{ }_{1} \varepsilon$
$R O A={ }_{2} \beta_{0}+{ }_{2} \beta_{1} \times \frac{D}{E}+{ }_{2} \varepsilon$

where:

- $\quad{ }_{i} \beta_{0}$ is the intercept of the regression line relative to the model $i(i=1,2)$;

- $\quad{ }_{i} \beta_{1}$ is the angular coefficient of the regression line $i$ and indicates the marginal effect of the independent variable on the dependent variable;

- ${ }_{i} \varepsilon$ is the error term.

The null hypothesis is the absence of a relationship between capital structure and the measures of performance:

$$
\mathrm{H}_{0}:{ }_{i} \beta_{1}=0
$$


The alternative hypothesis concerns, instead, the existence of a relationship between the independent variable and the dependent variable:

$$
\mathrm{H}_{1}: \quad{ }_{i} \beta_{1} \neq 0
$$

\section{FINDINGS AND DISCUSSIONS}

\subsection{FINANCIAL STRUCTURE AND ROE}

For the year 2015 we used a sample composed of n. 2,681 companies after eliminating the outliers.

There is a weak positive relationship: the Pearson coefficient reported in Table 2, with a value of 0.041 , is in the range of 0.00 $<\rho<0.19$ on the Evans scale. The $p$-value is lower than the $\alpha=0.05$ threshold and therefore the correlation coefficient can be considered significant at a level of $5 \%$.

Table 2: Correlation Matrix (year 2015)

\begin{tabular}{llcl}
\hline & & ROE & D/E \\
\hline \multirow{2}{*}{ ROE } & Pearson's $r$ & - & \\
& p-value & - & \\
\multirow{2}{*}{$D / E$} & Pearson's $r$ & $0.041^{*}$ & - \\
& p-value & 0.032 & - \\
\hline
\end{tabular}

$* p<.05, * * p<.01, * * * p<.001$

Table 3 refers to the coefficient of determination $\mathrm{R}^{2}$ of the corresponding regression model; its value was 0.002 : so, only $0.2 \%$ of variance in ROE is accounted by debt/equity ratio. The remaining $99.8 \%$ is due to factors not considered in the model.

Table 3: Coefficient of Determination (year 2015)

\begin{tabular}{ccc}
\hline Model & $\mathbf{R}$ & $\mathbf{R}^{\mathbf{2}}$ \\
\hline 1 & 0.041 & 0.002
\end{tabular}

Although significant at a level of 0.05 , the regression coefficient is close to zero as it is understood from Table 4: so, we can affirm that there is a weak positive relationship between the ROE and the debt/equity ratio.

Table 4: Regression Analysis Results (year 2015)

\begin{tabular}{ccccccc}
\hline Model & & Unstandardized & Standard Error & Standardized & $\mathbf{t}$ & $\mathbf{p}$ \\
\hline 1 & (Intercept) & 0.055 & 0.002 & & 23.925 & $<.001$ \\
& $D / E$ & 0.008 & 0.004 & 0.041 & 2.148 & 0.032 \\
\hline
\end{tabular}

In 2016 the sample is composed of n. 2,668 companies. According to the results in Table 5, Pearson coefficient define a weak positive relationship between variables. As for 2015, the $p$-value assumes a value lower than the significance threshold $\alpha=0.001$ : the correlation coefficient is significant.

Table 5: Correlation Matrix (year2016)

\begin{tabular}{llcc}
\hline & & ROE & D/E \\
\hline \multirow{2}{*}{ ROE } & Pearson's $r$ & - & \\
& p-value & - & \\
D/E & Pearson's $r$ & $0.068^{* * *}$ & - \\
& p-value & $<0.001$ & - \\
\hline${ }^{*} p<.05,{ }^{* *} p<.01,{ }^{* * *} p<.001$ & &
\end{tabular}

As reported in Table 6, the coefficient of determination $R^{2}$ was 0.005 that is only $0.5 \%$ of variance in ROE is accounted by debt/equity ratio. 
Table 6: Coefficient of determination (year 2016)

\begin{tabular}{ccc}
\hline Model & $\mathbf{R}$ & $\mathbf{R}^{\mathbf{2}}$ \\
\hline 1 & 0.068 & 0.005 \\
\hline
\end{tabular}

As for 2015, the results in Table 7 showed a weak positive relationship between ROE and debt/equity ratio.

Table 7: Regression Analysis Results (year 2016)

\begin{tabular}{ccccccc}
\hline Model & & Unstandardized & Standard Error & Standardized & $\mathbf{t}$ & $\mathbf{p}$ \\
\hline 1 & (Intercept) & 0.058 & 0.002 & & 25.104 & $<.001$ \\
& $D / E$ & 0.013 & 0.004 & 0.068 & 3.496 & $<.001$ \\
\hline
\end{tabular}

For the analysis conducted in 2017 we used a sample of n. 2,601 companies without outliers. We found a weak positive relationship between debt/equity ratio and ROE. As reported in Table 8, correlation coefficient is significant given the $p$-value below the level $\alpha=0.01$, so the correlation between financial structure and ROE is different from zero.

Table 8: Correlation Matrix (year2017)

\begin{tabular}{|c|c|c|c|}
\hline & & $R O E$ & $D / E$ \\
\hline \multirow{2}{*}{ ROE } & Pearson's r & - & \\
\hline & $p$-value & - & \\
\hline \multirow{2}{*}{$D / E$} & Pearson's r & $0.059 * *$ & - \\
\hline & $p$-value & 0.002 & - \\
\hline
\end{tabular}

The coefficient of determination $\mathrm{R}^{2}$ for $2017^{\prime}$ analysis is reported in Table 9; it was 0.004 that is only $0.4 \%$ of variance in ROE is accounted by debt/equity ratio. The remaining $99.6 \%$ is due to factors not considered in the model.

Table 9: Coefficient of d-Determination (year 2017)

\begin{tabular}{ccc}
\hline Model & $\mathbf{R}$ & $\mathbf{R}^{\mathbf{2}}$ \\
\hline 1 & 0.059 & 0.004 \\
\hline
\end{tabular}

The regression coefficient, with a significance level of 0.05 , is close to zero as we can observe from Table 10: so, we can confirm the existence of a weak positive relationship between capital structure and firm performance.

Table 10: Regression Analysis Results (year 2017)

\begin{tabular}{ccccccc}
\hline Model & & Unstandardized & Standard Error & Standardized & $\mathbf{t}$ & $\mathbf{p}$ \\
\hline 1 & (Intercept) & 0.062 & 0.002 & & 25.738 & $<.001$ \\
& $D / E$ & 0.012 & 0.004 & 0.059 & 3.027 & 0.002 \\
\hline
\end{tabular}

\subsection{FINANCIAL STRUCTURE AND ROA}

For the year 2015, the analysis about the relationship between ROA and capital structure consists of n. 2,761 companies remaining after eliminating the outliers. Table 11 reports the results for correlation with evidence of a weak positive relationship between the independent variable and the measure of performance. In this case, p-value is higher than the level of significance so the correlation coefficient is not significant.

Table 11: Correlation Matrix (year2015)

\begin{tabular}{llcc}
\hline & & ROA & D/E \\
\hline \multirow{2}{*}{ ROA } & Pearson's $r$ & - & \\
& p-value & - & \\
\multirow{2}{*}{$\boldsymbol{D} / \boldsymbol{E}$} & Pearson's $r$ & 0.011 & - \\
& p-value & 0.567 & - \\
\hline
\end{tabular}


${ }^{*} p<.05,{ }^{* *} p<.01,{ }^{* * *} p<.001$ The linear determination coefficient $\mathrm{R}^{2}$ reported in Table 12 (which value is 0.000 ) of the corresponding regression model suggests that the linear model cannot explain the variability of the ROA respect to the debt/equity ratio. The $100 \%$ of the variance in firm performance is due to factors not included in the model.

Table 12: Coefficient of determination (year 2015)

\begin{tabular}{ccc}
\hline Model & $\mathbf{R}$ & $\mathbf{R}^{\mathbf{2}}$ \\
\hline 1 & 0.011 & 0.000 \\
\hline
\end{tabular}

The coefficient of the linear regression is positive as it can be noted from Table 13, but its value is close to zero with a p-value of 0.567. This is higher than the significance threshold of $5 \%$ so we accepted the hypothesis of a coefficient equal to zero.

Table 13: Regression analysis results (year 2015)

\begin{tabular}{ccccccc}
\hline Model & & Unstandardized & Standard Error & Standardized & $\mathbf{t}$ & $\mathbf{p}$ \\
\hline 1 & (Intercept) & 0.037 & 0.001 & & 26.639 & $<.001$ \\
& $D / E$ & 0.001 & 0.002 & 0.011 & 0.573 & 0.567 \\
\hline
\end{tabular}

Sample for 2016 is composed of n. 2,761 companies; correlation coefficient is statistically significant. The p-value (0.021) is lower than the level $\alpha=0.05$ thus we can conclude that correlation is different from zero. Looking at Table 14 , the value of the Pearson coefficient identifies the existence of a very weak positive link between the financial structure and the ROA.

Table 14: Correlation Matrix (year2016)

\begin{tabular}{llcl}
\hline & & ROA & D/E \\
\hline \multirow{2}{*}{ ROA } & Pearson's $r$ & - & \\
& p-value & - & \\
D $/ \boldsymbol{E}$ & Pearson's $r$ & $0.044^{*}$ & - \\
& $p$-value & 0.021 & - \\
\hline${ }^{*} p<.05,{ }^{* *} p<.01,{ }^{* * *} p<.001$ & &
\end{tabular}

According to the results reported in Table $15, \mathrm{R}^{2}$ of the corresponding regression model resulting from the regression statistics is 0.002 ; thus, the linear model has a limited explanatory capacity.

Table 15: Coefficient of Determination (year 2016)

\begin{tabular}{ccc}
\hline Model & $\mathbf{R}$ & $\mathbf{R}^{\mathbf{2}}$ \\
\hline 1 & 0.044 & 0.002 \\
\hline
\end{tabular}

The regression coefficient is close to zero with a significance level of 0.05: as it can be understood from Table 16, for 2016 results showed a weak positive relationship between the ROA and the debt/equity ratio.

Table 16: Regression Analysis Results (year 2016)

\begin{tabular}{ccccccc}
\hline Model & & Unstandardized & Standard Error & Standardized & $\mathbf{t}$ & $\mathbf{p}$ \\
\hline 1 & (Intercept) & 0.036 & 0.001 & & 25.732 & $<.001$ \\
& $D / E$ & 0.005 & 0.002 & 0.044 & 2.310 & 0.021 \\
\hline
\end{tabular}

Analysis conducted for 2017 is based on a sample of n. 2,689 companies. The correlation analysis evidence a p-value higher than the $\alpha$ thresholds. Pearson coefficient, whose value (0.007) close to zero indicates no relation between the variables, is not significant as shown by the values in Table 17. 
Table 17: Correlation Matrix (year2017)

\begin{tabular}{llcc}
\hline & & ROA & D/E \\
\hline \multirow{2}{*}{ ROA } & Pearson's r & - & \\
& p-value & - & \\
D/E & Pearson's r & 0.007 & - \\
& p-value & 0.724 & - \\
\hline
\end{tabular}

$* \mathrm{p}<.05, * * \mathrm{p}<.01, * * * \mathrm{p}<.001$

As showed in Table 18, the value of the coefficient $R^{2}(0.000)$ suggests that $0 \%$ of the variability of the ROA is caused by financial structure; it is possible to state that $100 \%$ of it is attributable to factors that the linear model does not consider.

Table 18. Coefficient of Determination (year 2017)

\begin{tabular}{ccc}
\hline Model & $\mathbf{R}$ & $\mathbf{R}^{\mathbf{2}}$ \\
\hline 1 & 0.007 & 0.000 \\
\hline
\end{tabular}

P-value of the coefficient resultant from the analysis for this year is reported in Table 19: it is higher than the significance threshold of $5 \%$; therefore, we accept the hypothesis of nullity of the coefficient of the linear regression.

Table 19: Regression Analysis Results (year 2017)

\begin{tabular}{ccccccc}
\hline Model & & Unstandardized & Standard Error & Standardized & $\mathbf{t}$ & $\mathbf{p}$ \\
\hline 1 & (Intercept) & 0.040 & 0.002 & & 26.739 & $<.001$ \\
& $D / E$ & 0.865 & 0.002 & 0.007 & 0.353 & 0.724 \\
\hline
\end{tabular}

\section{CONCLUSION}

This paper wanted to test the assumption of the Modigliani and Miller Theory about the irrelevance of the financial structure and, thus, the absence of a relationship between capital structure and performance. The study covered the universe of European listed companies, surveyed through Bureau van Dijk's Amadeus database, in the period 2015 - 2017.

For the construction of the sample, from the reference population of n. 9,625 listed companies, n. 1,565 companies listed on the English market and n. 3,527 companies engaged in the provision of financial services and auxiliary activities of financial and insurance services were excluded. Their exclusion derived from the need to compare companies with homogeneous characteristics; in this regard, it should be noted that the English market is considered a liquid and efficient market unlike the other financial markets. On the other hand, with reference to financial companies, the exclusion derived from the different legal provision about financial statements in this sector respect to other economic sectors. In addition, companies with negative equity were excluded. Based on the literature review, ROE (return on equity) and ROA (return on assets) have been selected as dependent variables

Research showed the existence of a weak relationship between the debt/equity ratio and the measures of performance given the linear regression coefficient always close to zero. However, $R^{2}$ suggests a very limited explanatory capacity of the various models developed: thus, only a small part of the variability in performance measurements can be explained by changes in the explanatory variable of the financial structure. The remaining part is to be attributed to factors not included in the linear models formulated. In conclusion, financial structure expressed by the debt/equity ratio does not influence performance of European listed companies. This result is in line with the literature and in particular with the assertion of Modigliani and Miller (1958) and the studies of Long and Maliz (1986), of Fama and French (1998) and of Walaa Wahid ElKelish (2007).

\section{REFERENCES}

Arulvel., K., and Ajanthan., A. (2013). Capital Structure and Financial Performance: A Study Of Listed Trading Companies In Sri Lanka. ACADEMICIA, $3(6), 1-13$

Baum, C.F., Schafer, D., and Talavera, O. (2006). The effects of short-term liabilities on profitability: a comparison of German and US firms. Boston College Working Papers in Economics 636, Boston College Department of Economics. 
Eriotis, N., Franguoli, Z., and Neokosmides, Z. (2002). Profit margin and capital structure: an empirical relationship. The Journal of Applied Business Research, 18 (2), 85-88.

Evans, J. D. (1996). Straightforward statistics for the behavioral sciences. Pacific Grove, CA: Brooks/Cole Publishing.

Fama, E., and French, K. (1998). Taxes, financing decisions, and firm value. Journal of Finance, 53 (3), 819-843.

Filipovic, A.L., and Demirovic, S. (2016). The relationship between debt and profitability of stock companies in Montenegro. JCEBI, 3 (2), 19 - 34

Goddard, J., Tavakoli, M., and Wilson, J. (2005). Determinants of profitability in European manufacturing and services: Evidence from a dynamic panel data. Applied Financial Economics, 15 (18), 1269-282.

Joshua, A. (2005). "The effect of capital structure on profitability: an empirical analysis oflisted firms in Ghama”. Journal of Risk Finance, 6 (5), 438 445.

Long, M., and Malitz, I. (1986). The investment financing Nexus: Some empirical evidence. Midland Corporate Finance Journal, 3, 53-59.

Majumdar, S., and Chhibber, P. (1999). Capital structure and performance: Evidence from transition economy on an aspect of corporate governance. Public Choice, 98, 287-305.

Mashavave, F., and Tsaurai, K. (2015). Capital Structure and Profitability. A Case Of Jse Listed Companies. Risk governance and control: financial markets and institutions, 5 (1), 81-93.

Miller, M.H. (1977). Debt and tax. Journal of Finance, 32 (2), Papers and Proceedings of the Thirty-Fifth Annual Meeting of the American Finance Association, Atlantic City, New Jersey, 261-275.

Mujahid, M., and Akhtar, K. (2014). Impact of Capital Structure on Firms Financial Performance and Shareholders Wealth: Textile Sector of Pakistan. International Journal of Learning and Development, 4 (2), 27-33.

Ngobo, P.V., and Capiez, A. (2004). Structure du capital et performance de l'entreprise: le rôle modérateur des différences culturelles, Congrès de I'Association Internationale de Management Stratégique (AIMS), Le Havre.

Pornsit, J., and Yixin, L. (2008). Capital structure, staggered Boards, and firm Value. Financial Analysts Journal, 64 (1), 49-60.

Rahimian, M. (2016). The Relationship between Capital Structure and Profitability of Companies Listed in Tehran Stock Exchange. European Online Journal of Natural and Social Sciences, 5 (1), 128-131.

Sarkar, S., and Zapatero, F. (2003). The Trade-off Model with Mean Reverting Earnings: Theory and Empirical Tests. Economic Journal, 113 (490), $834-860$

Walaa, W. E. (2007), Financial structure and firm value: empirical evidence from the United Arab Emirates. International Journal of Business Research, 7 (1).

Zeitun, R., and Tian, G. (2007). Capital structure and corporate performance evidence from Jordan. Australasian Accounting Business and Finance Journal, 1 (4), 40-61. 